\title{
Overview of Systematic Reviews with Meta-Analysis Based on Randomized Controlled Trials of Balneotherapy and Spa Therapy from 2000 to 2019
}

This article was published in the following Dove Press journal: International Journal of General Medicine

\section{Hiroharu Kamioka' \\ Sachihiko Nobuoka ${ }^{2}$ \\ Junichi liyama $\mathbb{D}^{3}$}

'Faculty of Regional Environment Science, Tokyo University of Agriculture, Tokyo, Japan; ${ }^{2}$ Laboratory Medicine, St. Marianna University School of Medicine, Kanagawa, Japan; ${ }^{3}$ Department of Rehabilitation, Kumamoto Health Science University, Kumamoto, Japan
Correspondence: Hiroharu Kamioka Email hlkamiok@nodai.ac.jp
Background: The objectives of this review were to summarize systematic reviews with meta-analysis of balneotherapy (BT) and spa therapy (ST) based on randomized controlled trials, and to provide a perspective for future research.

Methods: Eligible studies were systematic reviews based on randomized controlled trials with meta-analysis that included at least one group treated with BT or ST. We searched the following databases for articles published in English from the year 2000 to 20 November 2019: Cochrane Database Systematic Review, MEDLINE, CINAHL, Web of Science, and Ichushi-Web.

Results: Eighteen studies met all inclusion criteria. Based on the International Classification of Diseases (ICD)-11, among these 18 studies, 8 (44\%) were about "\#15 Diseases of the musculoskeletal system or connective tissue", 5 (28\%) were about "\#21 Symptoms, signs or clinical findings, not elsewhere classified", 4 (22\%) were about "\#11 Diseases of the circulatory system", and 1 study (6\%) was about "\#8 Diseases of the nervous system". Both BT and ST provided significant pain relief and improved quality of life in chronic diseases of the musculoskeletal system and connective tissues. Additionally, BT and ST with exercise under water improved physical fitness and function in patients across diseases.

Conclusion: Researchers need to conduct studies on the treatment of many kinds of potential diseases using the keywords of pain relief and QoL. In addition, depending on patients' symptoms, physical fitness, and disabilities, performing exercise under water may improve treatment effects on physical function and fitness.

Keywords: balneotherapy, spa therapy, aquatic exercise, randomized controlled trials, pain, quality of life, rehabilitation

\section{Introduction}

Balneotherapy, ${ }^{1}$ has been frequently used globally as a complementary and/or alternative therapy. ${ }^{2-5}$ A recent systematic review (SR) showed that balneotherapy (BT) and spa therapy (ST) could significantly improve quality of life of patients with knee osteoarthritis. ${ }^{6}$ A review that performed a quality assessment of 51 randomized controlled trials (RCTs) based on ST identified each disease based on the International Classification of Diseases (ICD)-10. ${ }^{7}$ The findings identified 40 studies $(78 \%)$ that were about "Diseases of the musculoskeletal system and connective tissue" (eg, osteoarthritis, low back pain, fibromyalgia, ankylosing spondylitis, rheumatoid arthritis) and three studies (6\%) that were about "Diseases of the skin and subcutaneous tissue" (ie, atopic dermatitis and psoriasis). 
An SR based on RCTs is very important to demonstrate evidence of effective intervention, and can help decisionmakers interpret the deluge of published biomedical literature. We hoped to formulate a future research agenda for RCTs that would encourage more progress toward implementation of BT worldwide. Our study focused on all treatment and rehabilitation effects and health enhancements using the ICD-11. It is well known in research design that evidence grading is highest for an SR with meta-analysis (MA) of RCTs. Although many studies have reported the effects of BT and ST, there is no global review of SRs based on RCTs.

The objective of this review was to summarize SRs with MA of BT and ST based on RCTs and provide a perspective for future research.

\section{Approach}

This was an overview study for which we developed a protocol a priori. The detailed protocol was finalized on 15 November 2019 and is available from the corresponding author upon request.

\section{Scope of This Review}

We completely reviewed target SRs with MA based on the recommended structured abstracts ${ }^{8}$ and created a brief summary according to the ICD-11 numbering system. We also summarized the evidence and provided a perspective for future research.

\section{Terminology}

The terms "balneotherapy (BT)", "hydrotherapy (HT)", and "spa therapy (ST)" are frequently confused and tend to be used interchangeably; furthermore, the meaning of these words varies depending on the country and culture. ${ }^{9}$ We defined these terms as follows: based on terminology from recent studies. ${ }^{1,10,11}$ BT traditionally involved immersion in mineral and/or thermal waters from natural springs but may have interchangeably been defined as balneological interventions with natural gases $\left(\mathrm{CO}_{2}\right.$, sulphur, radon, etc.), peloids (mud), and other traditional remedies. ${ }^{1}$ HT generally employed normal tap water for medical treatment. We excluded HT in which the intervention was only immersion in tap water without aquatic exercise. ST employed a number of different treatment modalities, including HT and BT, often combined with massage, exercise, physical therapy, and/ or rehabilitation. We refer to target SRs in this paper as the use of all types of BT and ST for treatment and rehabilitation.
Aquatic exercise has various names such as water exercise, underwater exercise, and aquatic physical therapy, but in principle, it is referred to as aquatic exercise in this manuscript. However, in the structured abstracts of each study, we used the terms as written by the authors.

\section{Criteria for Considering Studies Included in This Review \\ Types of Studies}

Studies were eligible if they were SRs with MA based on RCT or quasi-RCT. There was no restriction on the basis of language.

\section{Types of Participants}

This study was a review based on SRs and was therefore restricted to original SRs of participants with any diseases. There were no restrictions on the type of disease to be treated by BA or ST.

\section{Comparator(s)/Control}

As controls, pre-planned stratified analyses were (a) placebo controls or waiting list controls, and (b) intervention groups that used different types of treatment, rehabilitation, and other therapies.

\section{Types of Interventions}

Studies that included at least one treatment group in which BA or ST was included.

\section{Types of Outcome Measures}

We focused on all treatment and rehabilitation effects using ICD-11. ${ }^{12}$

\section{Search Methodology for Identification of Studies Bibliographic Database Search Strategies}

We searched the following databases from 2000 up to 20 November 2019: MEDLINE via PubMed, CINAHL, Web of Science, and Ichushi Web (in Japanese). We also searched the Cochrane Database of Systematic Reviews up to 20 November 2019. All searches were performed by a specific searcher (hospital librarian, MM) who was qualified in medical information handling and was sophisticated in searches of clinical trials.

\section{Search Strategies}

The special search strategies contained the elements and terms for MEDLINE, CINAHL, Web of Science, Ichushi Web, and Cochrane Reviews (supplementary material). Only keywords about intervention were used for the searches. First, titles and 
abstracts of identified published articles were reviewed in order to determine the relevance of the articles. Next, references in relevant studies and identified SRs were screened.

\section{Handsearching and Reference Checking}

One author (HK) handsearched original articles in the Journal of Japanese Society of Balneology, Climatology, and Physical Medicine published from 2000 up to 30 November 2019.

\section{Review Methods}

\section{Selection of Studies}

In order to make the final selection of studies for the review, all criteria were applied by an author (HK) to the full text of articles that had passed the first eligibility screening (Figure 1). Uncertainties were resolved by discussion with other authors (SN, JI). Studies were selected when i) the design was an SR and ii) one of the interventions was a form of spa bathing. Treatment and rehabilitation effects were used as a primary outcome measure. Trials that were excluded are presented with reasons for exclusion (supplementary material).

The literature searches based on databases included potentially relevant articles (Figure 1). Abstracts from those articles were assessed, and 40 papers were retrieved for further evaluation (checks for relevant literature). Twentytwo publications were excluded because they did not meet the eligibility criteria.

\section{Quality Assessment of Included Studies}

We did not perform a quality assessment of each article.

\section{Summary of Studies and Data Extraction}

One author (HK) described the summary from each article based on the structured abstracts, and other authors (SN, JI) confirmed the contents of each SR. We used ICD-11 to categorize each target disease in the SRs.

\section{Results}

\section{Study Selection and Characteristics (Conclusions on Each Study)}

Eighteen studies ${ }^{2,3,6,13-27}$ met all inclusion criteria (Figure 1 and supplementary material). The contents of all articles were summarized as structured abstracts and outlined in reverse chronological order.

Saquetto et $\mathrm{al}^{13}$ reported that water-based exercise improved muscle strength, balance, mobility, aerobic capacity,

Manuscripts based on databases
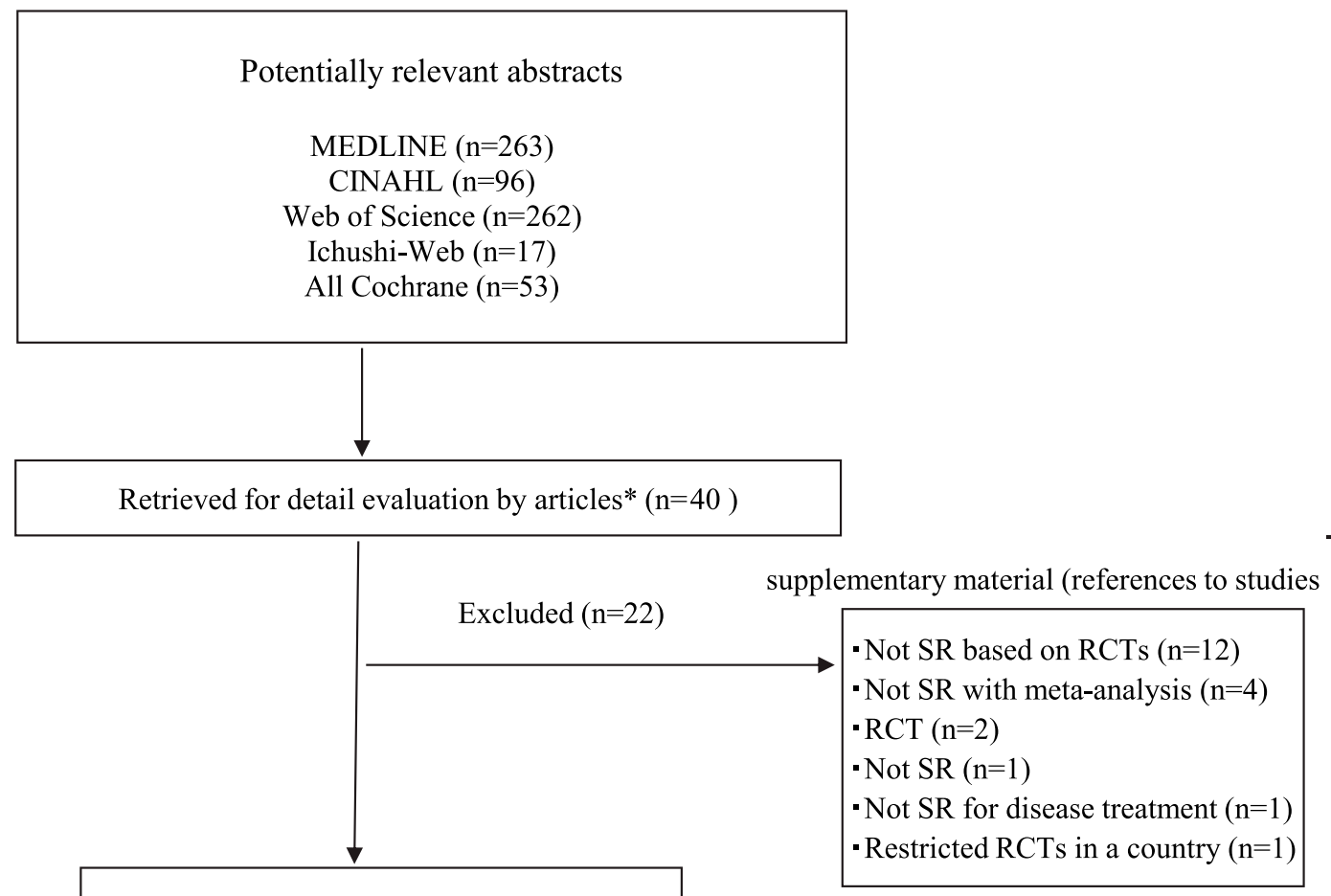

Articles meeting inclusion criteria $(\mathrm{n}=18)$

Figure I Flowchart of trial process.

Note: *Reduplication. 
functional reach, joint position sense, and quality of life (QoL) in poststroke patients. Bai et $\mathrm{al}^{14}$ reported that ST can benefit pain relief and improve lumbar spine function among patients with chronic low back pain (CLBP). de Moraes Silva et al ${ }^{15}$ identified that BT may result in a moderate improvement in pain, QoL, and skin pigmentation changes for patients with chronic venous insufficiency, and it had no clear effect on disease severity, signs, and symptom scores, adverse effects, leg ulcers, and edema when compared with no treatment. Liang et al $^{16}$ reported that aquatic exercise benefited patients with ankylosing spondylitis by reducing disease activity and alleviating pain, but did not improve functional capacity or spinal mobility. Antonelli et al ${ }^{6}$ showed that BT and ST significantly improved QoL of patients with knee osteoarthritis (OA).

Källström et $\mathrm{al}^{17}$ reported that infrared sauna bath (Waon therapy) was associated with short-term improvement in cardiac function among patients with heart failure. Yeung et $\mathrm{l}^{18}$ concluded that current evidence indicated no significant benefit of aqua lymphatic therapy over standard land-based care for improving lymphedema status or physical function in people with upper limb lymphedema. Rocha Conceição et al $^{19}$ identified favorable effects of sauna (Waon therapy) on natriuretic peptides and blood pressure in patients with heart failure.

Bartels et $\mathrm{al}^{20}$ reported that aquatic exercise had small, short-term, and clinically relevant effects on patient-reported pain, disability, and QoL in people with knee and hip OA. Xiang et $\mathrm{al}^{21}$ observed that functional improvement of the knee joint in patients with knee OA treated with mudpack therapy was not significantly different from that of control subjects at the end of a 4-month follow-up period. Verhagen et $\mathrm{al}^{2}$ noted that, in terms of pain, some benefits were associated with addition of radon to carbon dioxide baths for the treatment of patients with rheumatoid arthritis (RA), but the clinical relevance of these benefits was small. Baker et $\mathrm{al}^{22}$ reported that aquatic exercise had moderate beneficial effects on pain, physical function, and QoL in adults with musculoskeletal diseases.

Bidonde et $\mathrm{al}^{23}$ observed that aquatic training improved wellness, symptoms, and fitness in adults with fibromyalgia. Similarly, Naumann et $\mathrm{al}^{24}$ found moderate-to-strong evidence that therapeutic BT resulted in small improvements in pain and health-related QoL in patients with fibromyalgia. Lima et $\mathrm{al}^{25}$ also reported that aquatic therapy had significant effects on physical function, QoL, and stiffness in patients with fibromyalgia during a period of longer than 20 weeks. Liu et $\mathrm{al}^{26}$ observed that mud therapy was a favorable option for pain relief in patients with knee OA. Verhagen et $\mathrm{al}^{3}$ found evidence for the beneficial effects of mineral baths compared to no treatment in OA. Pittler et $\mathrm{al}^{27}$ reported encouraging evidence that ST and BT were effective for treating patients with low back pain.

\section{Disease Classification of Target Studies}

Based on ICD-11, we identified a disease targeted in each article (Table 1). Among the 18 studies, 8 (44\%) targeted "\#15 Diseases of the musculoskeletal system or connective tissue”, 5 (28\%) targeted “\#21 Symptoms, signs or clinical findings, not elsewhere classified", 4 (22\%) targeted "\#11 Diseases of the circulatory system", and 1 study (6\%) targeted "\#8 Diseases of the nervous system".

\section{Brief Summary of Effectiveness}

A brief summary of primary outcomes was tabulated across diseases (Table 2). Pain relief was commonly effective in many studies, apart from the degree of effect (effect size) in BT and ST with or without aquatic exercise. Improvement in QoL was also significant among inter-disease in five studies. As for the elements of physical fitness and function, aquatic exercise produced a significant improvement in almost all studies.

On the other hand, interventions without exercise under water (ie, mineral water immersion, mudpack/peloids) had similar results with little significant effect. With respect to heart failure, sauna intervention (Waon therapy) resulted in significant effects on some outcomes, but there was also a discrepancy between the two studies that measured this outcome. Other diseases (ie, chronic venous insufficiency and lymphedema) produced little significant improvement in the pathology or symptoms of the disease.

\section{Discussion}

This is the first overview of SRs with MA based on only RCTs for treatment and rehabilitation with BT and ST during the last two decades. There was a summary of SRs based on RCTs of water immersion therapies a decade ago, ${ }^{4}$ but it was limited to just water immersion and did not include as many RCT-designed studies compared with trials from the last decade. The current review strengthened the evidence by covering a broader range of issues. Furthermore, this study was unique in its summary of ICD-11 disease status in each study, and its listing of intervention effects by outcome across diseases. 
Table I ICD-I I of Target Diseases in Each Article

\begin{tabular}{|c|c|c|c|c|c|c|}
\hline Chapter & Classification & Disease Name & ICD code & $\begin{array}{l}\text { Reference } \\
\text { No. }\end{array}$ & Author (Year) & Intervention Type \\
\hline I & $\begin{array}{l}\text { Certain infectious or parasitic } \\
\text { diseases }\end{array}$ & & & & & \\
\hline 2 & Neoplasms & & & & & \\
\hline 3 & $\begin{array}{l}\text { Diseases of the blood or blood- } \\
\text { forming organs }\end{array}$ & & & & & \\
\hline 4 & Diseases of the immune system & & & & & \\
\hline 5 & $\begin{array}{l}\text { Endocrine, nutritional or } \\
\text { metabolic diseases }\end{array}$ & & & & & \\
\hline 6 & $\begin{array}{l}\text { Mental, behavioral or } \\
\text { neurodevelopmental disorders }\end{array}$ & & & & & \\
\hline 7 & Sleep-wake disorders & & & & & \\
\hline 8 & Diseases of the nervous system & Stroke & $8 B 20$ & [13] & Saquetto (2019) & Water-based exercise \\
\hline 9 & Diseases of the visual system & & & & & \\
\hline 10 & $\begin{array}{l}\text { Diseases of the ear or mastoid } \\
\text { process }\end{array}$ & & & & & \\
\hline \multirow[t]{4}{*}{ II } & $\begin{array}{l}\text { Diseases of the circulatory } \\
\text { system }\end{array}$ & Lymphedema & BD93 & [18] & Yeung (2018) & Aquatic therapy \\
\hline & & Heart failure & BDIO & {$[17]$} & Källström (2018) & $\begin{array}{l}\text { Balneotherapy (sauna: } \\
\text { Waon therapy) }\end{array}$ \\
\hline & & & & [19] & $\begin{array}{l}\text { Rocha Conceição } \\
(2018)\end{array}$ & $\begin{array}{l}\text { Balneotherapy (sauna: } \\
\text { Waon therapy) }\end{array}$ \\
\hline & & $\begin{array}{l}\text { Chronic venous } \\
\text { insufficiency }\end{array}$ & BD74 & {$[15]$} & De Moraes Silva (2019) & Balneotherapy \\
\hline 12 & $\begin{array}{l}\text { Diseases of the respiratory } \\
\text { system }\end{array}$ & & & & & \\
\hline 13 & Diseases of the digestive system & & & & & \\
\hline 14 & Diseases of the skin & & & & & \\
\hline \multirow[t]{8}{*}{15} & $\begin{array}{l}\text { Diseases of the musculoskeletal } \\
\text { system or connective tissue }\end{array}$ & $\begin{array}{l}\text { Osteoarthritis of } \\
\text { knee }\end{array}$ & FAOI & [6] & Antonelli (2018) & $\begin{array}{l}\text { Balneotherapy, spa } \\
\text { therapy }\end{array}$ \\
\hline & & & & {$[21]$} & Xiang (2016) & Mudpack therapy \\
\hline & & & & [20] & Bartels (2016) & Aquatic exercise \\
\hline & & & & [26] & Liu (2013) & Mud therapy \\
\hline & & & & [3] & Verhagen (2007) & Balneotherapy \\
\hline & & $\begin{array}{l}\text { Osteoarthritis of } \\
\text { hip }\end{array}$ & FA00 & [20] & *Bartels (2016) & *Aquatic exercise \\
\hline & & & & [3] & *Verhagen (2007) & *Balneotherapy \\
\hline & & $\begin{array}{l}\text { Osteoarthritis of } \\
\text { other specified joint }\end{array}$ & FA03 & [3] & *Verhagen (2007) & *Balneotherapy \\
\hline
\end{tabular}


Table I (Continued).

\begin{tabular}{|c|c|c|c|c|c|c|}
\hline Chapter & Classification & Disease Name & ICD code & $\begin{array}{l}\text { Reference } \\
\text { No. }\end{array}$ & Author (Year) & Intervention Type \\
\hline & & $\begin{array}{l}\text { Rheumatoid } \\
\text { arthritis }\end{array}$ & FA20 & [2] & Verhagen (2015) & $\begin{array}{l}\text { Balneotherapy, spa } \\
\text { therapy }\end{array}$ \\
\hline & & $\begin{array}{l}\text { Ankylosing } \\
\text { spondylitis }\end{array}$ & FA02.0z & {$[16]$} & Liang (2019) & Balneotherapy \\
\hline & & $\begin{array}{l}\text { Musculoskeletal } \\
\text { diseases (including } \\
\text { osteoarthritis, } \\
\text { rheumatoid } \\
\text { arthritis, and } \\
\text { osteoporosis) }\end{array}$ & $\begin{array}{l}\text { FA0I-03 } \\
\text { FA20 FB83.I }\end{array}$ & [22] & Baker (2014) & Aquatic exercise \\
\hline 16 & $\begin{array}{l}\text { Diseases of the genitourinary } \\
\text { system }\end{array}$ & & & & & \\
\hline 17 & $\begin{array}{l}\text { Conditions related to sexual } \\
\text { health }\end{array}$ & & & & & \\
\hline 18 & $\begin{array}{l}\text { Pregnancy, childbirth or the } \\
\text { puerperium }\end{array}$ & & & & & \\
\hline 19 & $\begin{array}{l}\text { Certain conditions originating in } \\
\text { the perinatal period }\end{array}$ & & & & & \\
\hline 20 & Developmental anomalies & & & & & \\
\hline \multirow[t]{6}{*}{21} & $\begin{array}{l}\text { Symptoms, signs or clinical } \\
\text { findings, not elsewhere } \\
\text { classified }\end{array}$ & $\begin{array}{l}\text { Fibromyalgia } \\
\text { (chronic primary } \\
\text { pain) }\end{array}$ & MG30.0 & [23] & Bidonde (20|4) & Aquatic exercise \\
\hline & & & & [24] & Naumann (2014) & Balneotherapy \\
\hline & & & & [25] & Lima (2013) & Aquatic physical therapy \\
\hline & & $\begin{array}{l}\text { Low back pain } \\
\text { (including chronic } \\
\text { pain) }\end{array}$ & ME84.2 & [14] & Bai (2019) & Spa therapy \\
\hline & & & & [27] & Pittler (2006) & $\begin{array}{l}\text { Spa therapy, } \\
\text { balneotherapy }\end{array}$ \\
\hline & & $\begin{array}{l}\text { Musculoskeletal } \\
\text { diseases (including } \\
\text { fibromyalgia and } \\
\text { low back pain) }\end{array}$ & $\begin{array}{l}\text { MG30.0 } \\
\text { ME84.2 }\end{array}$ & [22] & *Baker (20|4) & Aquatic exercise \\
\hline 22 & $\begin{array}{l}\text { Injury, poisoning or certain } \\
\text { other consequences of external } \\
\text { causes }\end{array}$ & & & & & \\
\hline 23 & $\begin{array}{l}\text { External causes of morbidity or } \\
\text { mortality }\end{array}$ & & & & & \\
\hline 24 & $\begin{array}{l}\text { Factors influencing health status } \\
\text { or contact with health services }\end{array}$ & & & & & \\
\hline 25 & Codes for special purposes & & & & & \\
\hline
\end{tabular}

(Continued) 
Table I (Continued).

\begin{tabular}{|l|l|l|l|l|l|l|}
\hline Chapter & Classification & Disease Name & ICD code & $\begin{array}{l}\text { Reference } \\
\text { No. }\end{array}$ & Author (Year) & Intervention Type \\
\hline 26 & $\begin{array}{l}\text { Supplementary Chapter } \\
\text { Traditional Medicine Conditions }\end{array}$ & & & & & \\
\hline
\end{tabular}

Note: *Reduplication.

\section{Overall Effectiveness of Treatment and Rehabilitation}

Both BT and ST had significant pain-relieving effects in chronic diseases of the musculoskeletal system and connective tissue. The warmth and buoyancy of water may block nociception by acting on thermal receptors and mechano-receptors, thus influencing spinal segmental mechanisms. ${ }^{28,29}$ Warm water may also enhance blood flow, help dissipate algogenic chemicals, and facilitate muscle relaxation. Furthermore, the hydrostatic effect of water may relieve pain by reducing peripheral edema ${ }^{30-33}$ and dampening sympathetic nervous system activity. ${ }^{34,35}$ Additionally, due to a lower specific heat, mudpack/ peloids and mineral water immersion elevate the bodycore temperature more efficiently. ${ }^{36}$

BT and ST consistently and significantly improved the patient's QoL. Pain and QoL are closely related. Pain and functional impairment with difficulty to perform daily living activities can cause a serious reduction in QoL. ${ }^{37} \mathrm{~A}$ health economics study reported that patients with knee OA lost about 1.9 quality-adjusted-life years (QALY). ${ }^{38}$ Therefore, reducing patient pain is extremely important and can lead to drug reduction. Improvements in QoL may be due to the types of treatment that are acceptable to patients, which are usually based on a low side effect profile and on patients' preferences, ${ }^{2,4,26}$ in addition to the pain relief mechanisms described above. In fact, few studies reported side effects and there were no serious adverse events.

In terms of improving physical fitness and function, this review found that it depends on whether the intervention (ie, BT or ST) included aquatic exercise. Buoyancy decreases compressive weight-bearing stresses on joints and allows functional exercise with lessened gravitational load, improving both strength and range of movement. ${ }^{39}$ Water resistance facilitates strengthening and encourages aerobic exercise in people who experience pain or difficulties with land-based exercises, and minimizes the risk of joint or muscle injury. ${ }^{40}$ In addition, the aquatic environment allows higher-intensity exercises to be undertaken, with lower cardiovascular stress than is possible on land. ${ }^{41}$ Therefore, additional aquatic exercise enhances not only functionality of the affected site in a patient but also the physical fitness component of the whole body. This suggests that movement under water is required for active rehabilitation, in addition to pain relief.

\section{Current Evidence and Research Challenges}

Based on current evidence from SRs, we propose challenges that researchers should undertake in the near future to treat patients with various diseases (Figure 2). First, because the mechanisms of pain relief are well known, it is now necessary to conduct well-designed clinical trials (ie, RCTs) and MA for other chronic diseases with pain. In fact, although there are no SRs that include only RCTs, there have been studies of neck pain ${ }^{42}$ and multiple sclerosis. ${ }^{43}$

Improvement of symptoms and partial and whole-body functions and symptoms from aquatic exercise are expected to be effective not only for diseases of the musculoskeletal system or connective tissue but also for many other diseases such as those that involve the nervous system ${ }^{44,45}$ and circulatory system. ${ }^{46}$ A recent SR without MA reported aquatic exercise was effective for improving motor skills in children with cerebral palsy. ${ }^{47}$ Depending on the patient's physical characteristics and symptoms, BT and ST may contribute to pain reduction (including reduction of analgesic and/or NSAID consumption), improved QoL, and improved function in a variety of potential diseases.

Although we have summarized specific effects on outcome across diseases, researchers planning to conduct clinical trials will need to set appropriate outcomes for each intervention while avoiding the error of multiple comparisons.

\section{Current Problems with SRs}

SRs with MA help to synthesize and update the literature using a valuable methodology for evidence-based medicine. However, serious issues have been reported for 
Table 2 Brief Summary by Primary Outcome Among Inter-Diseases on Target Systematic Reviews

\begin{tabular}{|c|c|c|c|c|c|}
\hline Outcome & Intervention Type & $\begin{array}{l}\text { Significant Effect Compared } \\
\text { with Control }\end{array}$ & Disease & $\begin{array}{l}\text { Reference } \\
\text { No. }\end{array}$ & $\begin{array}{l}\text { Author } \\
\text { (Year) }\end{array}$ \\
\hline \multirow[t]{14}{*}{ Pain } & Spa therapy & Significant & Low back pain & {$[14]$} & Bai (2019) \\
\hline & Balneotherapy & Significant & $\begin{array}{l}\text { Chronic venous } \\
\text { insufficiency }\end{array}$ & {$[15]$} & $\begin{array}{l}\text { de Moraes Silva } \\
(2019)\end{array}$ \\
\hline & Water therapy & Significant & $\begin{array}{l}\text { Ankylosing } \\
\text { spondylitis }\end{array}$ & {$[16]$} & Liang (2019) \\
\hline & $\begin{array}{l}\text { Balneotherapy, spa } \\
\text { therapy }\end{array}$ & Significant & $\begin{array}{l}\text { Osteoarthritis of } \\
\text { knee }\end{array}$ & [6] & $\begin{array}{l}\text { Antonelli } \\
(2018)\end{array}$ \\
\hline & Aquatic exercise & Significant & $\begin{array}{l}\text { Osteoarthritis of } \\
\text { knee and hip }\end{array}$ & {$[20]$} & Bartles (2016) \\
\hline & $\begin{array}{l}\text { Balneotherapy (mineral } \\
\text { water) }\end{array}$ & Significant & $\begin{array}{l}\text { Rheumatoid } \\
\text { arthritis }\end{array}$ & {$[2]$} & $\begin{array}{l}\text { Verhagen } \\
(2015)\end{array}$ \\
\hline & Mudpack therapy & Significant & $\begin{array}{l}\text { Osteoarthritis of } \\
\text { knee }\end{array}$ & {$[21]$} & Xiang (20|6) \\
\hline & Balneothrapy (mudpack) & $\begin{array}{l}\text { Significant for improving/Not } \\
\text { significant for intensity }\end{array}$ & $\begin{array}{l}\text { Rheumatoid } \\
\text { arthritis }\end{array}$ & [2] & $\begin{array}{l}\text { Verhagen } \\
(2015)\end{array}$ \\
\hline & Aquatic exercise & Significant & $\begin{array}{l}\text { Musculoskeletal } \\
\text { diseases }\end{array}$ & {$[22]$} & Baker (20|4) \\
\hline & Balneotherapy & Significant & Fibromyalgia & {$[24]$} & $\begin{array}{l}\text { Naumann } \\
(2014)\end{array}$ \\
\hline & Mud therapy & Significant & $\begin{array}{l}\text { Osteoarthritis of } \\
\text { knee }\end{array}$ & {$[26]$} & Liu (2013) \\
\hline & Balneotherapy & Significant & Osteoarthritis & [3] & $\begin{array}{l}\text { Verhagen } \\
(2007)\end{array}$ \\
\hline & Balneotherapy & Significant & Low back pain & {$[27]$} & Pittler (2006) \\
\hline & Spa therapy & Significant & Low back pain & {$[27]$} & Pittler (2006) \\
\hline \multirow[t]{5}{*}{ QoL } & Balneotherapy & Significant & $\begin{array}{l}\text { Chronic venous } \\
\text { insufficiency }\end{array}$ & {$[15]$} & $\begin{array}{l}\text { de Moraes Silva } \\
(2019)\end{array}$ \\
\hline & $\begin{array}{l}\text { Balneotherapy, spa } \\
\text { therapy }\end{array}$ & Significant & $\begin{array}{l}\text { Osteoarthritis of } \\
\text { knee }\end{array}$ & [6] & $\begin{array}{l}\text { Antonelli } \\
(2018)\end{array}$ \\
\hline & Aquatic exercise & Significant & $\begin{array}{l}\text { Osteoarthritis of } \\
\text { knee and hip }\end{array}$ & {$[20]$} & Bartles (2016) \\
\hline & Aquatic exercise & Significant & $\begin{array}{l}\text { Musculoskeletal } \\
\text { diseases }\end{array}$ & {$[20]$} & Baker (2014) \\
\hline & Balneotherapy & Significant & Fibromyalgia & {$[24]$} & $\begin{array}{l}\text { Naumann } \\
(20 \mid 4)\end{array}$ \\
\hline Depression & Balneotherapy & Not significant & Fibromyalgia & [24] & $\begin{array}{l}\text { Naumann } \\
(2014)\end{array}$ \\
\hline Mobility/partial function & Aquatic exercise & Significant & $\begin{array}{l}\text { Osteoarthritis of } \\
\text { knee and hip }\end{array}$ & {$[20]$} & Bartles (2016) \\
\hline
\end{tabular}

(Continued) 
Table 2 (Continued).

\begin{tabular}{|c|c|c|c|c|c|}
\hline Outcome & Intervention Type & $\begin{array}{l}\text { Significant Effect Compared } \\
\text { with Control }\end{array}$ & Disease & $\begin{array}{l}\text { Reference } \\
\text { No. }\end{array}$ & $\begin{array}{l}\text { Author } \\
\text { (Year) }\end{array}$ \\
\hline & Aquatic exercise & Significant & Fibromyalgia & {$[23]$} & Bidonde (20|4) \\
\hline & Mudpack therapy & Significant & $\begin{array}{l}\text { Osteoarthritis of } \\
\text { knee and hip }\end{array}$ & {$[21]$} & Xiang (2016) \\
\hline & Mudpack therapy & Not significant & $\begin{array}{l}\text { Rheumatoid } \\
\text { arthritis }\end{array}$ & {$[2]$} & $\begin{array}{l}\text { Verhagen } \\
(2015)\end{array}$ \\
\hline & Water-based exercise & Significant & Stroke & [13] & $\begin{array}{l}\text { Squettoto } \\
(2019)\end{array}$ \\
\hline & Spa therapy & Significant & Low back pain & {$[14]$} & Bai (2019) \\
\hline & Water therapy & Not significant & $\begin{array}{l}\text { Ankylosing } \\
\text { spondylitis }\end{array}$ & {$[16]$} & Liang (2019) \\
\hline \multirow[t]{2}{*}{ Muscle strength } & Water-based exercise & Significant & Stroke & [13] & $\begin{array}{l}\text { Squettoto } \\
(2019)\end{array}$ \\
\hline & Aquatic exercise & Significant & Fibromyalgia & {$[23]$} & Bidonde (20|4) \\
\hline \multirow[t]{4}{*}{ Stiffness/tender joint } & Mudpack therapy & Significant & $\begin{array}{l}\text { Rheumatoid } \\
\text { arthritis }\end{array}$ & {$[2]$} & $\begin{array}{l}\text { Verhagen } \\
(2015)\end{array}$ \\
\hline & Aquatic exercise & Significant & Fibromyalgia & {$[23]$} & Bidonde (2014) \\
\hline & Balneotherapy & Significant & Fibromyalgia & {$[24]$} & $\begin{array}{l}\text { Naumann } \\
(2014)\end{array}$ \\
\hline & Aquatic physical therapy & Significant & Fibromyalgia & {$[25]$} & Lima (2013) \\
\hline \multirow{6}{*}{$\begin{array}{l}\text { Physical (whole) } \\
\text { function }\end{array}$} & Spa therapy & Not significant & Low back pain & {$[14]$} & Bai (2019) \\
\hline & Water therapy & Not significant & $\begin{array}{l}\text { Ankylosing } \\
\text { spondylitis }\end{array}$ & {$[16]$} & Liang (2019) \\
\hline & Aquatic therapy & Not significant & Lymphedema & {$[18]$} & Yeung (20|8) \\
\hline & Aquatic exercise & Significant & $\begin{array}{l}\text { Musculoskeletal } \\
\text { diseases }\end{array}$ & {$[22]$} & Baker (20|4) \\
\hline & Aquatic exercise & Significant & Fibromyalgia & {$[23]$} & Bidonde (2014) \\
\hline & Aquatic physical therapy & Significant & Fibromyalgia & {$[25]$} & Lima (2013) \\
\hline Balance & Water-based exercise & Significant & Stroke & [13] & $\begin{array}{l}\text { Squettoto } \\
(2019)\end{array}$ \\
\hline \multirow[t]{3}{*}{ Gait speed } & Water-based exercise & Significant & Stroke & [13] & $\begin{array}{l}\text { Squettoto } \\
(2019)\end{array}$ \\
\hline & Aquatic exercise & Significant & Fibromyalgia & {$[23]$} & Bidonde (2014) \\
\hline & Aquatic physical therapy & Significant & Fibromyalgia & {$[25]$} & Lima (2013) \\
\hline Aerobic capacity & Water-based exercise & Significant & Stroke & {$[13]$} & $\begin{array}{l}\text { Squettoto } \\
(2019)\end{array}$ \\
\hline Disease activity & Water therapy & Significant & $\begin{array}{l}\text { Ankylosing } \\
\text { spondylitis }\end{array}$ & {$[16]$} & Liang (2019) \\
\hline
\end{tabular}

(Continued) 
Table 2 (Continued).

\begin{tabular}{|c|c|c|c|c|c|}
\hline Outcome & Intervention Type & $\begin{array}{l}\text { Significant Effect Compared } \\
\text { with Control }\end{array}$ & Disease & $\begin{array}{l}\text { Reference } \\
\text { No. }\end{array}$ & $\begin{array}{l}\text { Author } \\
\text { (Year) }\end{array}$ \\
\hline Oedema & Balneotherapy & Not significant & $\begin{array}{l}\text { Chronic venous } \\
\text { insufficiency }\end{array}$ & {$[15]$} & $\begin{array}{l}\text { de Moraes Silva } \\
(2019)\end{array}$ \\
\hline Skin pigmentation & Balneotherapy & Significant & $\begin{array}{l}\text { Chronic venous } \\
\text { insufficiency }\end{array}$ & {$[15]$} & $\begin{array}{l}\text { de Moraes Silva } \\
(2019)\end{array}$ \\
\hline Leg ulcers & Balneotherapy & Not significant & $\begin{array}{l}\text { Chronic venous } \\
\text { insufficiency }\end{array}$ & {$[15]$} & $\begin{array}{l}\text { de Moraes Silva } \\
(2019)\end{array}$ \\
\hline \multirow[t]{4}{*}{$\begin{array}{l}\text { Specific sign and } \\
\text { symptom of disease }\end{array}$} & Balneotherapy & Not significant & $\begin{array}{l}\text { Chronic venous } \\
\text { insufficiency }\end{array}$ & {$[15]$} & $\begin{array}{l}\text { de Moraes Silva } \\
(2019)\end{array}$ \\
\hline & $\begin{array}{l}\text { Balneotherapy (sauna: } \\
\text { Waon therapy) }\end{array}$ & Not significant* & Heart failure & [17] & $\begin{array}{l}\text { Källström } \\
(2018)\end{array}$ \\
\hline & $\begin{array}{l}\text { Balneotherapy (sauna: } \\
\text { Waon therapy) }\end{array}$ & Significant & Heart failure & [19] & $\begin{array}{l}\text { Rocha } \\
\text { Conceição } \\
(2018)\end{array}$ \\
\hline & Aquatic therapy & Not significant & Lymphedema & {$[18]$} & Yeung (20|8) \\
\hline \multirow[t]{2}{*}{ Blood biomarker } & $\begin{array}{l}\text { Balneotherapy (sauna: } \\
\text { Waon therapy) }\end{array}$ & Not significant & Heart failure & [17] & $\begin{array}{l}\text { Källström } \\
(2018)\end{array}$ \\
\hline & $\begin{array}{l}\text { Balneotherapy (sauna: } \\
\text { Waon therapy) }\end{array}$ & Significant & Heart failure & [19] & $\begin{array}{l}\text { Rocha } \\
\text { Conceição } \\
(2018)\end{array}$ \\
\hline \multirow[t]{2}{*}{$\begin{array}{l}\text { Imaging for heart } \\
\text { function }\end{array}$} & $\begin{array}{l}\text { Balneotherapy (sauna: } \\
\text { Waon therapy) }\end{array}$ & Significant $* *$ & Heart failure & [17] & $\begin{array}{l}\text { Källström } \\
(2018)\end{array}$ \\
\hline & $\begin{array}{l}\text { Balneotherapy (sauna: } \\
\text { Waon therapy) }\end{array}$ & Not significant & Heart failure & [19] & $\begin{array}{l}\text { Rocha } \\
\text { Conceição } \\
(2018)\end{array}$ \\
\hline
\end{tabular}

Notes: *Blood pressure. **Significant effect on three items of five outcomes.

SRs. ${ }^{48-52}$ The production of SRs has markedly increased across several disciplines. Recent studies concluded that the number of RCTs published has been extremely small compared to the mass production of SRs. ${ }^{48,49}$ Conversely, the number of SRs has increased compared to the number of RCTs, and SRs with overlapping themes are increasing worldwide. Redundant SRs add to the ongoing waste of research resources, time, and effort across disciplines. ${ }^{50}$ Furthermore, overlapping SRs are known to occasionally reach conflicting conclusions based on genuine and defendable differences. ${ }^{51,52}$

There were multiple SRs with the same theme in our study. We excluded SRs that did not perform MA or that included a study design other than RCT, but when combined, there were many duplicated SRs. A methodologist has suggested that the publication of SRs should be realigned to remove biases and vested interests, and to better integrate them with the primary production of evidence. ${ }^{51}$ It is important to rigorously evaluate the evidence obtained, and recently a tool for assessing recommendations of clinical practice guidelines was developed. ${ }^{53}$ Although we utilized a critical appraisal tool (AMSTAR 2) ${ }^{54}$ to arrange the publication status of SRs of BT and ST, identify their status in ICD-11, and indicate future research challenges, we did not conduct quality assessments of SRs. This is a major weakness of our study.

Most targeted SRs in our study suggested that included studies showed methodological flaws that resulted in a high risk of bias. Common themes in SR studies were insufficient sample size, unclear randomization, insufficient doubleblind design, and lack of intention-to-treat analysis. 


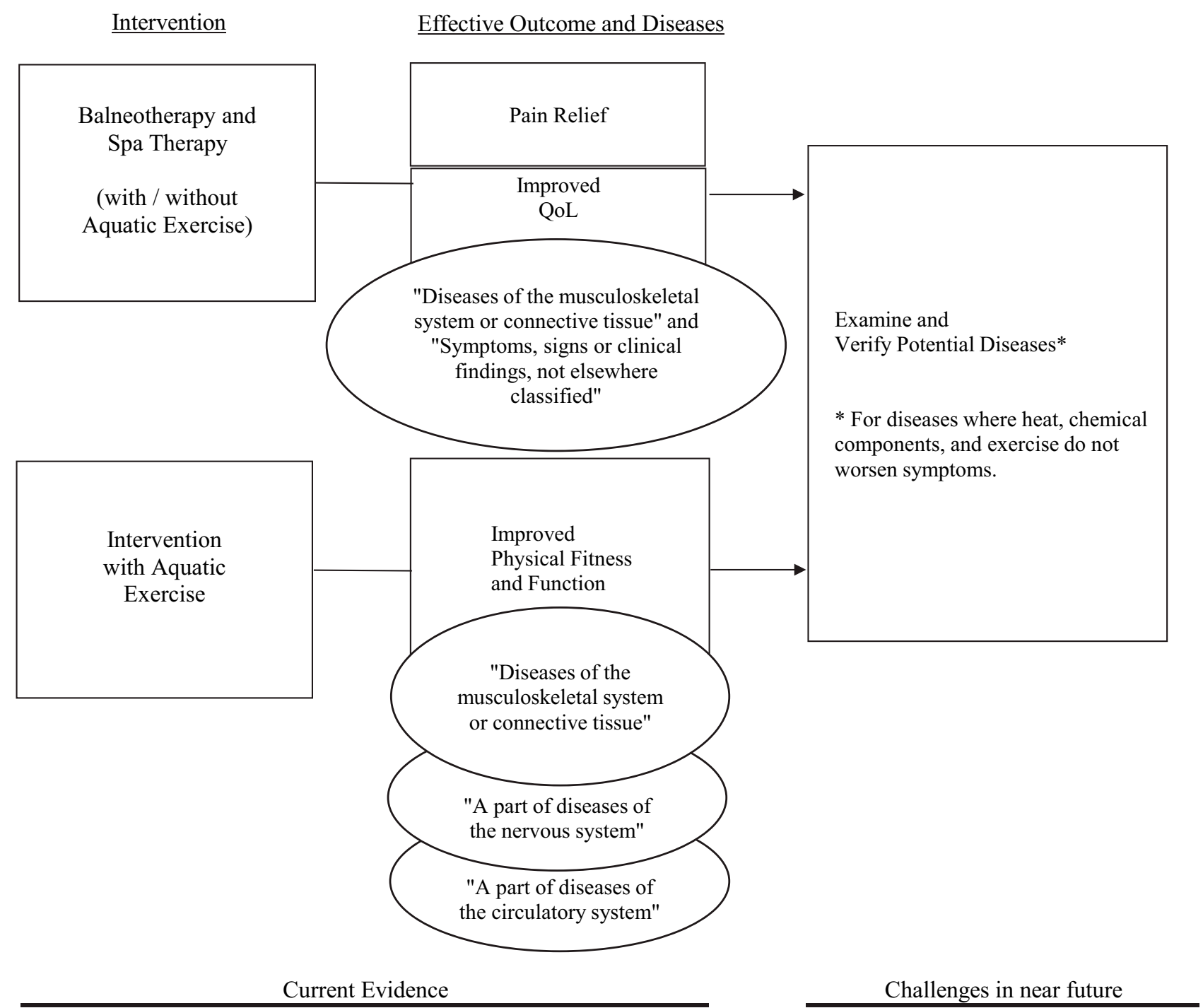

Figure 2 Current evidence and research challenge.

\section{Limitations}

This review had several limitations that should be acknowledged. First, some selection criteria were common across SRs; however, bias remained due to differences in eligibility for participation, which were described in each original article. Furthermore, a weakness of this study is the possibility that important SRs were overlooked because the PICOS setting criterion might not have been fully appropriate. Second, publication bias was a limitation due to inadequate use of multiple databases for each SR. In fact, this study did not use the Physiotherapy Evidence Database (PEDro), a free database of over 47,000 RCTs, SRs, and clinical practice guidelines in physiotherapy that are focused on rehabilitation and non-pharmacological participants. Although there was no linguistic restriction in the eligibility criteria, we searched studies with only English and Japanese keywords. Third, although we defined BT and ST separately, there were slight differences in the definitions in each SR. Fourth, we created a brief summary, but it did not reflect effect size by considering standardized mean difference, mean difference, or relative risk. Fifth, due to differences in the definitions of several words in each SR, BT and ST could sometimes not be strictly distinguished. Sixth, as mentioned earlier (see section on 'Current problems with SRs'), there were multiple SRs with the same research theme, and they were included without any quality assessment. Last, the purpose of this study was to summarize the characteristics of SRs with MA, but a weak point is that it was difficult to interpret the obtained evidence because it did not evaluate the quality of each SR. 


\section{Conclusions}

Both BT and ST provide significant pain relief effects and improved QoL in chronic diseases of the musculoskeletal system or connective tissue. Additionally, BT and ST with exercise under water may improve physical fitness and function in patients across diseases.

Researchers need to conduct studies on the treatment of many kinds of potential diseases using the keywords of pain relief and QoL. In addition, depending on patients' symptoms, physical fitness, and disabilities, conducting exercise under water may improve effects on physical function and fitness.

\section{Abbreviations}

BT, balneotherapy; ICD, the International Classification of Diseases; HT, hydrotherapy; MA, meta-analysis; OA, osteoarthritis; QoL, quality of life; RA, rheumatoid arthritis; RCT, randomized controlled trial; SR, systematic review; ST, spa therapy.

\section{Acknowledgment}

We are thankful for the generous assistance provided by Ms Michiko Ishida (paperwork) and Ms Mari Makishi (searches and acquired the data).

\section{Author Contributions}

HK conceived and designed the study. HK made a brief summary of included studies and data extraction and matched ICD-11 with each target SR. SN and JI are the guarantors. All authors made substantial contributions to conception and design, acquisition of data, or analysis and interpretation of data; took part in drafting the article or revising it critically for important intellectual content; gave final approval of the version to be published; and agree to be accountable for all aspects of the work.

\section{Funding}

There is no funding to report.

\section{Disclosure}

The authors declared no conflicts of interest with respect to the research, authorship and/or publication of this article.

\section{References}

1. Fioravanti A, Karagulle M, Bender T, Karagulle MZ. Balneotherapy in osteoarthritis: facts, fiction and gaps in knowledge. Eur J Integr Med. 2017;9:148-150. doi:10.1016/j.eujim.2017.01.001
2. Verhagen AP, Bierma-Zeinstra SMA, Boers M, et al. Balneotherapy (or spa therapy) for rheumatoid arthritis. Cochrane Database Syst Rev. 2015;2:CD000518. doi:10.1002/14651858.CD000518

3. Verhagen AP, Bierma-Zeinstra SMA, Boers M, et al. Balneotherapy for osteoarthritis. Cochrane Database Syst Rev. 2007;4:CD006864.

4. Kamioka H, Tsutani K, Okuizumi H, et al. Effectiveness of aquatic exercise and balneotherapy: a summary of systematic reviews based on randomized controlled trials of water immersion therapies. J Epidemiol. 2010;20(1):2-12. doi:10.2188/jea.JE20090030

5. Cimbiz A, Bayazit V, Hallaceli H, Cavlak U. The effect of combined therapy (spa and physical therapy) on pain in various chronic diseases. Complement Ther Med. 2005;13:244-250.

6. Antonelli M, Donelli D, Fioravanti A. Effects of balneotherapy and spa therapy on quality of life of patients with knee osteoarthritis: a systematic review and meta-analysis. Rheumatol Int. 2018;38:1807-1824. doi:10. 1007/s00296-018-4081-6.

7. Kamioka H, Tsutani K, Maeda M, et al. Assessing the quality of study reports on spa therapy based on randomized controlled trials by the spa therapy checklist (SPAC). Complement Ther Clin Pract. 2014;20:317-333.

8. Beller EM, Glasziou PP, Altman DG, et al. PRISMA for abstracts: reporting systematic reviews in journal and conference abstracts. PLoS Med. 2013;10(4):e1001419. doi:10.1371/journal.pmed.1001419

9. Gutenbrunner C, Bender T, Cantista P, Karagülle M. A proposal for a worldwide definition of health resort medicine balneology, medical hydrology and climatology. Int J Biometeorol. 2010;54(5):495-507. doi:10.1007/s00484-010-0321-5

10. Kardes S, Karagülle M, Gecmen I, Adigüzel T, Yücesoy H, Karagülle MZ. Outpatient balneological treatment of osteoarthritis in older persons: a retrospective study. Z Gerontol Geriatr. 2018. doi:10.1007/s00391-018-1370-3

11. Karagülle M, Kardeş S, Karagülle MZ. Long-term efficacy of spa therapy in patients with rheumatoid arthritis. Rheumatol Int. 2018;38 (3):353-362. doi:10.1007/s00296-017-3926-8

12. WHO. International classification of diseases 11th revision: the global standard for diagnostic health information. Available from: https://icd.who.int/en/. Accessed July 6, 2020.

13. Saquetto MB, da Silva CM, Martinez BP, et al. Water-based exercise on functioning and quality of life in post stroke persons: a systematic review and meta-analysis. J Stroke Cerebrovasc Dis. 2019;28 (11):104341. doi:10.1016/j.jstrokecerebrovasdis.2019.104341.

14. Bai R, Li C, Xiao Y, Sharma M, Zhang F, Zhao Y. Effectiveness of spa therapy for patients with chronic low back pain: an updated systematic review and meta-analysis. Medicine (Baltimore). 2019;98 (37):e17092. doi:10.1097/MD.0000000000017092.

15. de Moraes Silva MA, Nakano LC, Cisneros LL, Miranda F Jr. Balneotherapy for chronic venous insufficiency. Cochrane Database Syst Rev. 2019;26(8):CD013085. doi:10.1002/14651858.CD013085.

16. Liang Z, Fu C, Zhang Q, et al. Effects of water therapy on disease activity, functional capacity, spinal mobility and severity of pain in patients with ankylosing spondylitis: a systematic review and meta-analysis. Disabil Rehabil. 2019;29:1-8. doi:10.1080/0963 8288.2019.1645218.

17. Källström M, Soveri I, Oldgren J, et al. Effects of sauna bath on heart failure: a systematic review and meta-analysis. Clin Cardiol. 2018;41 (11):1491-1501. doi:10.1002/clc.23077.

18. Yeung W, Semciw AI. Aquatic therapy for people with lymphedema: a systematic review and meta-analysis. Lymphat Res Biol. 2018;16 (1):9-19. doi:10.1089/1rb.2016.0056.

19. Rocha Conceição LS, de Queiroz JG, Neto MG, Martins-Filho PRS, Carvalho VO. Effect of Waon therapy in individuals with heart failure: a systematic review. J Card Fail. 2018;24(3):204-206. doi:10.1016/j.cardfail.2018.01.008.

20. Bartels EM, Juhl CB, Christensen R, et al. Aquatic exercise for the treatment of knee and hip osteoarthritis. Cochrane Database Syst Rev. 2016;17(3):CD005523. 
21. Xiang J, Wu D, Li J. Clinical efficacy of mudpack therapy in treating knee osteoarthritis: a meta-analysis of randomized controlled studies. Am J Phys Med Rehabil. 2016;95(2):121-131. doi:10.1097/PHM.0 000000000000354

22. Baker AL, Talevski J, Morello RT, Brand CA, Rahmann AE, Urquhart DM. Effectiveness of aquatic exercise for musculoskeletal conditions: a meta-analysis. Arch Phys Med Rehabil. 2014;95 (9):1776-1786. doi:10.1016/j.apmr.2014.04.005

23. Bidonde L, Busch AJ, Schachter CL, et al. Aquatic exercise training for fibromyalgia. Cochrane Database Syst Rev. 2014;10(3):CD01 1336.

24. Naumann J, Sadaghiani C. Therapeutic benefit of balneotherapy and hydrotherapy in the management of fibromyalgia syndrome: a qualitative systematic review and meta-analysis of randomized controlled trials. Arthritis Res Ther. 2014;16(4):R141. doi:10.1186/ ar4603.

25. Lima TB, Dias JM, Mazuquin BF, et al. The effectiveness of aquatic physical therapy in the treatment of fibromyalgia: a systematic review with meta-analysis. Clin Rehabil. 2013;27(10):892-908. doi:10.1177/ 0269215513484772

26. Liu H, Zeng C, Gao SG, et al. The effect of mud therapy on pain relief in patients with knee osteoarthritis: a meta-analysis of randomized controlled trials. J Int Med Res. 2013;41(5):1418-1425. doi:10.1177/0300060513488509.

27. Pittler MH, Karagülle MZ, Karagülle M, Ernst E. Spa therapy and balneotherapy for treating low back pain: meta-analysis of randomized trials. Rheumatology (Oxford). 2006;45(7):880-884. doi:10. 1093/rheumatology/kel018

28. Bender T, Karagülle Z, Bálint GP, Gutenbrunner C, Bálint PV, Sukenik S. Hydrotherapy, balneotherapy, and spa treatment in pain management. Rheumatol Int. 2005;25(3):220-224. doi:10.1007/ s00296-004-0487-4

29. Yamazaki F, Endo Y, Torii R, Sagawa S, Shiraki K. Continuous monitoring of change in hemodilution during water immersion in humans: effect of water temperature. Aviat Space Environ Med. 2000;71(6):632-639.

30. Gabrielsen A, Videbaek R, Johansen LB, et al. Forearm vascular and neuroendocrine responses to graded water immersion in humans Acta Physiol Scand. 2000;169(2):87-94. doi:10.1046/j.1365-201x. 2000.00680.x

31. Becker BE. Aquatic therapy: scientific foundations and clinical rehabilitation applications. Phys Med Rehabil. 2009;1:859-872.

32. Hayes SC, Ruel-Hirche H, Turner J. Exercise and secondary lymphedema: safety, potential benefits, and research issues. Med Sci Sports Exerc. 2009;41(3):483-489. doi:10.1249/MSS.0b013e31818b98fb

33. Forestier RJ, Briancon G, Francon A, Erol FB, Mollard JM. Balneohydrotherapy in the treatment of chronic venous insufficiency. VASA. 2014;43(5):365-371. doi:10.1024/0301-1526/ a000374

34. Mooventhan A, Nivethitha L. Scientific evidence-based effects of hydrotherapy on various systems of the body. Am J Med Sci. 2014;6(5):199-209. doi:10.4103/1947-2714.132935

35. Fam AG. Spa treatment in arthritis: a rheumatologist's view. J Rheumatol. 1991;18(12):1775-1777.

36. Maeda T, Kudo Y, Horiuchi T, et al. Clinical and anti-aging effect of mud-bathing therapy for patients with fibromyalgia. Mol Cell Biochem. 2017;444:87-92.

37. Hunter DJ, Schofield D, Callander E. The individual and socioeconomic impact of osteoarthritis. Nat Rev Rheumatol. 2014;10 (7):437-441. doi:10.1038/nrrheum.2014.44
38. Losina E, Walensky RP, Reichmann WM, et al. Impact of obesity and knee osteoarthritis on morbidity and mortality in older Americans. Ann Intern Med. 2011;154:217-226.

39. Poyhonen T, Sipila S, Keskinen KL, Hautala A, Savolainen J, Malkia E. Effects of aquatic resistance training on neuromuscular performance in healthy women. Med Sci Sports Exerc. 2002;34 (12):2103-2109. doi:10.1249/01.MSS.0000039291.46836.86

40. Onodera S, Yoshioka A, Nishimura K, et al. Water exercise and health promotion. J Sports Med Phys Fitness. 2013;2:393-399.

41. Hall J, Grant J, Blake D, Taylor G, Garbutt G. Cardiorespiratory responses to aquatic treadmill walking in patients with rheumatoid arthritis. Physiother Res Int. 2004;9(2):59-73. doi:10.1002/pri.303

42. Corvillo I, Armijo F, Álvarez-Badilo A, Armijo O, Varela E, Maraver F. Efficacy of aquatic therapy for neck pain: a systematic review. Int J Biometeorol. 2019. doi:10.1007/s00484-019-01738-6.

43. Corvillo I, Verela E, Armijo F, Alvarez-badillo AO, Maraver F, Maraver F. Efficacy of aquatic therapy for multiple sclerosis: a systematic review. Eur J Phys Rehabil Med. 2017;53(6):944-952. doi:10.23736/S1973-9087.17.04570-1

44. Terrens AF, Soh SE, Morgan PE. The efficacy and feasibility of aquatic physiotherapy for people with Parkinson's disease: a systematic review. Disabil Rehabil. 2018;40(24):2847-2856. doi:10.1080/09638288.2017.1362710.

45. Pinto C, Salazar AP, Marchese RR, Stein C, Pagnussat AS. The effects of hydrotherapy on balance, functional mobility, motor status, and quality of life in patients with Parkinson disease: a systematic review and meta-analysis. Am Acad Phys Med Rehabil. 2019;11:278-291. doi:10.1016/j.pmrj.2018.09.031.

46. Verhagan AP, Cardoso JR, Bierma-Zeinstra SM. Aquatic exercise \& balneotherapy in musculoskeletal conditions. Best Pract Res Clin Rheumatol. 2012;26(3):335-343. doi:10.1016/j.berh.2012.05.008

47. Roostaei M, Baharlouei H, Azadi H, Fragala-Pinkham MA. Effects of aquatic intervention on gross motor skills in children with cerebral palsy: a systematic review. Phys Occup Ther Pediatr. 2017;37 (5):496-515. doi:10.1080/01942638.2016.1247938

48. Niforatos JD, Weaver M, Johansen ME. Assessment of publication trends of systematic reviews and randomized clinical trials, 1995 to 2017. JAMA Intern Med. 2019;179(11):1593-1594. doi:10.1001/ jamainternmed.2019.3013

49. Doundoulakis I, Antza C, Apostolidou-Kiouti F, et al. Overview of systematic reviews of non-vitamin $\mathrm{K}$ oral anticoagulants in atrial fibrillation: evidence of publication overlap. Circ Cardiovasc Qual Outcomes. 2018;11(12):e004769. doi:10.1161/CIRCOUTCOMES.118.004769

50. Ioannidis JPA. The mass production of redundant, misleading, and conflicted systematic reviews and meta-analysis. Milkbank $Q$. 2016;94(39):485-514. doi:10.1111/1468-0009.12210

51. Siontis KC, Ioannidis JPA. Replication, duplication, and waste in a quarter million systematic reviews and meta-analysis. Circ Cardiovasc Qual Outcomes. 2018;12:e05212. doi:10.1161/CIRC OUTCOMES.118.005212

52. Bolland MJ, Grey A, Devaney J. A case study of discordant overlapping meta-analyses: vitamin D supplements and fracture. PLoS One. 2014;9(12):e115934. doi:10.1371/journal.pone.0115934

53. Brouwers MC, Spithoff K, Kerkvliet K, et al. Development and validation of a tool to assess the quality of clinical practice guideline recommendations. JAMA Netw Open. 2020;3(5):e205535. doi:10.1001/jamanetworkopen.2020.5535

54. Shea BJ, Reeves BC, Wells G, et al. AMSTAR 2: a critical appraisal tool for systematic reviews that include randomized or non-randomised studies of healthcare interventions, or both. BMJ. 2017;358:j4008. 


\section{Publish your work in this journal}

The International Journal of General Medicine is an international, peer-reviewed open-access journal that focuses on general and internal medicine, pathogenesis, epidemiology, diagnosis, monitoring and treatment protocols. The journal is characterized by the rapid reporting of reviews, original research and clinical studies across all disease areas. The manuscript management system is completely online and includes a very quick and fair peer-review system, which is all easy to use. Visit http://www.dovepress.com/ testimonials.php to read real quotes from published authors.

Submit your manuscript here: https://www.dovepress.com/international-journal-of-general-medicine-journal 